Vol 2. No 1. Februari 2018

ISSN 2580-5029

\title{
IDENTIFIKASI DAN PREVALENSI TELUR CACING PARASIT PADA FESES SAPI (BoS sp.) YANG DIGEMBALAKAN DI TEMPAT PEMBUANGAN AKHIR SAMPAH (TPAS) TAMANGAPA MAKASSAR
}

\author{
Cut Muthiadin ${ }^{1}$, Isna Rasdianah Aziz ${ }^{1}$, Firdayana ${ }^{1}$ \\ ${ }^{1}$ Jurusan Biologi, Fakultas Sains dan Teknologi, Universitas Islam Negeri Alauddin Makassar, \\ Indonesia \\ *Emaill: isna.rasdianah@gmail.com
}

\begin{abstract}
Grazing the cows not only on the grass, but today there are at landfill. This study aimed to determine the type of parasitic worms in cow feces and to determine the prevalence of worm eggs in the feces of cattle in pastored around the landfill Tamangapa Makassar. Identification qualitatively using flotation method, whereas quantitative using Mc. Master method. The identification results obtained from 25 samples of cow feces, there are 3 types of positive samples containing worm eggs Oesophagostomum sp. and Cooperia sp. using the floating method. While using Mc. Master method showed nothing of the worm eggs.
\end{abstract}

Keywords: cow (Bos sp.), feces, worm egg

\begin{abstract}
ABSTRAK
Pengembalaan sapi tidak hanya dilapangan rumput, namun saat ini juga dilakukan di Tempat Pembuangan Akhir Sampah (TPAS). Penelitian ini bertujuan untuk mengetahui jenis telur cacing parasit pada feses sapi dan untuk mengetahui prevalensi telur cacing pada feses sapi yang digembalakan di sekitar tempat pembuangan akhir sampah (TPAS) Tamangapa Makassar. Identifikasi secara kualitatif dengan menggunakan metode apung (Flotation methode). Sedangkan secara kuantitatif menggunakan metode Mc. Master. Data identifikasi yang diperoleh dari 25 sampel feses sapi terdapat 3 sampel yang positif mengandung jenis telur cacing Oesophagostomum sp. dan Cooperia sp. yang diperoleh dengan menggunakan metode apung. Sedangkan dengan metode Mc. Master, tidak ditemukan telur cacing.
\end{abstract}

Kata Kunci: feses, sapi (Bos sp.), telur cacing

\section{PENDAHULUAN}

Usaha peternakan sapi tidak hanya menghasilkan daging atau susu, tetapi juga menghasilkan pupuk kandang dan sebagai lahan pembukaan lapangan kerja (Setiawan,
2014). Di Sulawesi Selatan sendiri, gross populasi ternak sapi tumbuh rata-rata $11,46 \%$ per tahun, di atas pertumbuhan ratarata nasional yang 10,26\% per tahun (Paly, 2013). Minat masyarakat untuk beternak sapi 
mengalami peningkatan setiap tahunnya. Kunci keberhasilan dalam usaha peningkatan produktivitas ternak sapi yaitu kesehatan ternak itu sendiri (Kertawirawan dkk, 2012).

Salah satu penyakit pada ternak sapi adalah infeksi cacing parasit gastrointestinal yang dapat menyebabkan kerugian dari segi ekonomi, diantaranya penurunan berat badan, penurunan kualitas daging, jeroan dan kulit, penurunan produktivitas ternak dan bahaya penularan pada manusia (Rahayu, 2015).

Penggembalaan sapi saat ini tidak hanya di lapangan rumput, namun juga digembalakan di Tempat Pembuangan Akhir Sampah (TPAS). Sapi yang digembalakan di TPAS mendapatkan asupan makanan dari sampah organik yang terfermentasi, tetapi terdapat efek samping yang kurang baik bagi kesehatan sapi terutama serangan parasit yang hidup di tempat lembab tersebut (Nezar, 2014).

Salah satu TPAS di Makassar yang dimanfaatkan sebagai tempat penggembalaan sapi adalah TPAS Tamangapa dengan populasi sapi terbesar di Kota Makassar. Pengembalaan di tempat pembuangan akhir sampah (TPAS) dapat menyebabkan sapi terkena penyakit akibat terjangkit oleh parasit cacing. Salah satu cara mengetahui adanya cacing parasit dengan identifikasi telur cacing pada feses. Dengan mengetahui hal tersebut, maka segera dapat dilakukan pengobatan dengan jenis antelmintika yang tepat, sehingga pengobatannya menjadi lebih efektif (Vivi, 2015).

\section{METODE}

Penelitian ini dilakukan pada bulan September 2016 di lingkungan tempat pembuangan akhir sampah (TPAS) Tamangapa yang terletak di Jalan Tamangapa Jalur Antang Raya Kota Makassar dan Laboratorium Parasitologi Balai Besar Veteriner (BBVET) Maros, Sulawesi Selatan.

Pengambilan Sampel Feses. Feses sapi diambil menggunakan kantong plastik di TPAS baik di kandang atau tempat sapi digembalakan. Segera setelah sapi defekasi, kapas yang telah diberi formalin 10\% dimasukkan ke dalam kantong plastik yang berisi sampel untuk mencegah menetasnya telur selama pengangkutan dan penyimpanan. Memberikan setiap sampel tanda atau label, kemudian sampel dimasukkan dalam frezer hingga dilakukan identifikasi

Identifikasi Telur Cacing. Identifikasi dilakukan secara kualitatif menggunakan metode apung (flotation method) dan secara kuantitatif dengan menggunakan metode $M c$. Master. Sampel feses diambil sebanyak 2 gram dan ditambahkan garam jenuh sebanyak $30 \mathrm{ml}$. Feses dan larutan pengapung diaduk sampai homogen dengan menggunakan mortar kemudian disaring ke dalam tabung sentrifus hingga mencapai volume $15 \mathrm{ml}$. Sentrifus dengan kecepatan 1500 rpm 5 menit. Garam jenuh ditambahkan hingga permukaan cairan tepat di atas 
permukaan tabung. Deck glass diletakkan di atas tabung selama 5 menit kemudian diperiksa di bawah mikroskop untuk melihat morfologi telur. Jenis cacing diidentifikasi menggunakan manual book dan buku identifikasi (Pusarawati dkk, 2013; Grabda, 1991; Kabata, 1985).

Kuantitas telur cacing dihitung dengan menggunakan metode Mc Master dengan menimbang feses sapi sebanyak 2 gram. Akuades ditambahkan sebanyak $28 \mathrm{ml}$, diaduk hingga homogen dengan menggunakan mortar. Tabung sentrifus diisi dengan $1 \mathrm{ml} \mathrm{NaCl}$ menggunakan pipet pasteur dan ditambahkan $1 \mathrm{ml}$ campuran feses yang telah dilarutkan. Setelah itu di pipet ke dalam kamar Mc. Master dan didiamkan selama 20 menit supaya telur dan kista mengapung ke permukaan. Jumlah telur yang terlihat dihitung pada tiap kolom dengan menggunakan rumus (Zajac and Conboy, 2012):

$$
E P G=2 n \times 50
$$

Ket: EPG: egg per gram (telur cacing per gram) feses $\mathrm{n}$ : jumlah telur cacing yang terhitung dalam kamar hitung

Data yang dikumpulkan dianalisis dengan menghitung prevalensi jumlah sampel yang positif dibagi dengan jumlah keseluruhan sampel yang diperiksa dan dikalikan $100 \%$.

\section{HASIL DAN PEMBAHASAN}

Sampel berupa feses sapi diambil langsung dari kandang yang berada di TPAS yaitu di Lingkungan Kassi Kelurahan Tamangapa Kecamatan Manggala. Jenis ternak sapi yang dipelihara oleh masyarakat daerah tersebut adalah sapi Ongole. Pengambilan sampel dilakukan sebanyak $2 x$ dan sampel yang digunakan adalah sebanyak 25 sampel. Berdasarkan hasil pengamatan dan identifikasi pada 25 sampel feses sapi, sampel yang positif terdapat telur cacing sebanyak 3 sampel dan ditemukan 2 jenis telur cacing, tertera pada tabel 1 . 
Tabel 1. Jenis telur cacing yang ditemukan dan hasil identifikasi pada feses sapi yang digembalakan di tempat pembuangan akhir sampah (TPAS) Tamangapa Makassar.

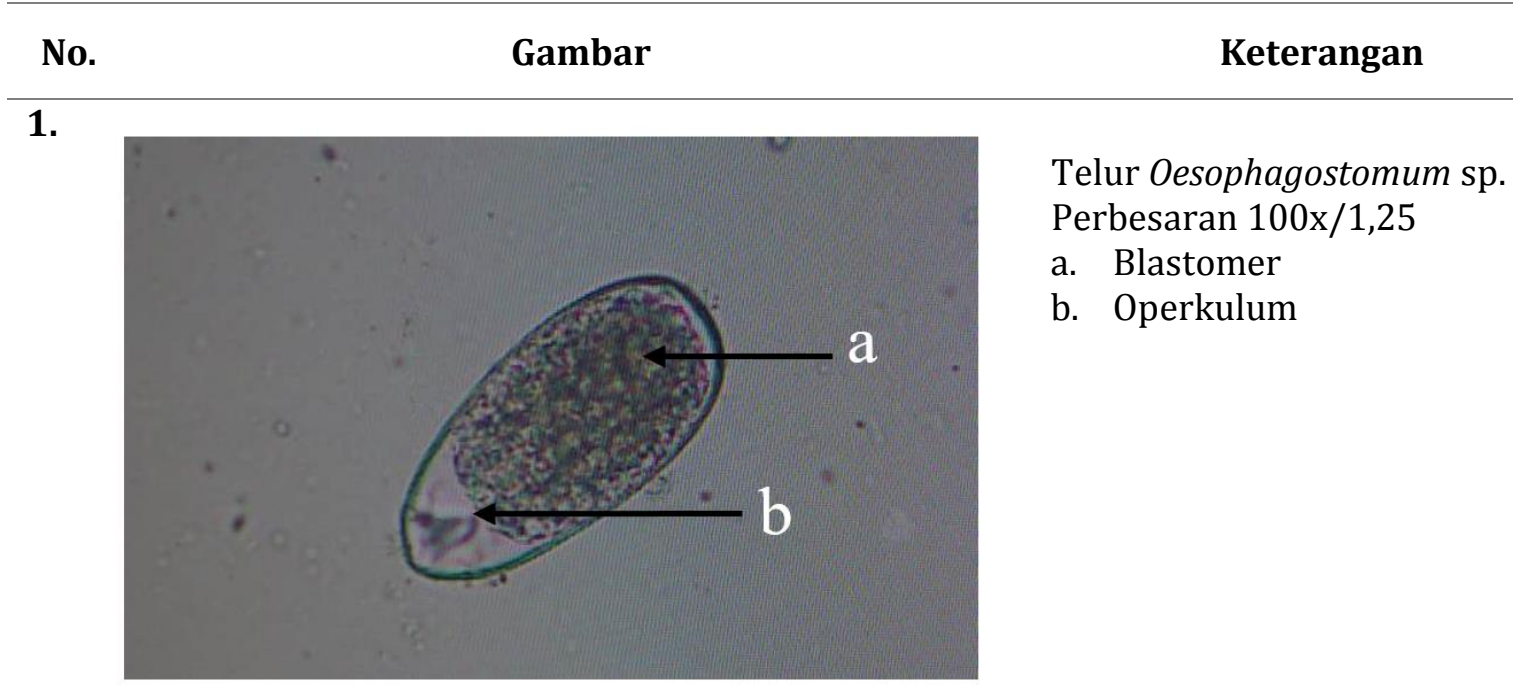

2

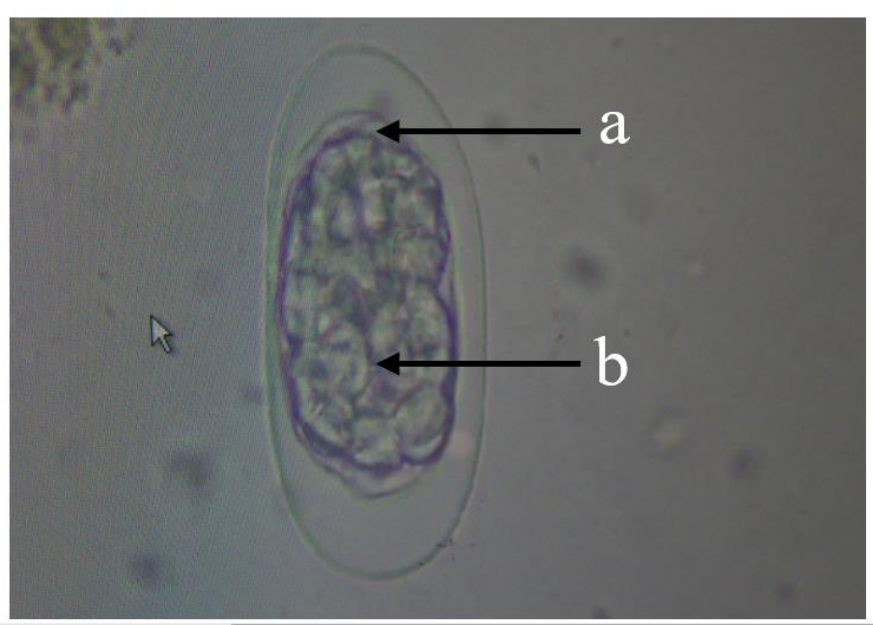

Telur Cooperia sp.

Perbesaran 100x/1,25

a. Operkulum

b. Blastomer

Cacing Oesophagostomum sp. (cacing dalam usus manusia jika termakan. Gejala bungkul) termasuk nematoda umum ditandai dengan nyeri perut, diare gastrointestinal dan menjadi parasit di dalam persisten dan penurunan berat badan usus besar, hati dan lambung sapi dengan (Yelifari et al., 2005).

bentuk nodul bulat berwarna merah. Gejala Cacing Cooperia sp. (cacing gilig) klinis akibat infeksi cacing ini menyebabkan berkembang di usus halus dan menginfestasi hewan menjadi kurus, feses berwarna hitam, sapi secara peroral atau melalui mulut lunak bercampur lendir dan darah segar. (Rahayu, 2015). Gejala infeksi pada ternak Cacing ini juga mampu berkembang biak sapi antara lain diare, lemah, anemia, 
dehidrasi dan berat badan menurun (Widjaja, 2014).

Berdasarkan uji Mc. Master, penentuan jumlah telur cacing per gram (EPG) menunjukkan hasil negatif karena tidak adanya telur cacing yang ditemukan. Tingkat infeksi parasit gastrointestinal ini tidak dapat ditentukan. Berdasarkan standar infeksi, infeksi dapat dikategorikan ringan jika jumlah telur yang dihitung sejumlah 1-499 butir tiap gram, infeksi sedang ditunjukkan jika jumlah telur 500-5000 butir tiap gram dan infeksi berat ditunjukkan jika telur yang dihasilkan $>5000$ butir tiap gram feses ternak (Levine, 1990; Soulsby, 1982).

Ketidakberadaan telur cacing yang diuji dengan metode Mc. Master disebabkan karena jumlah sampel yang digunakan sedikit yaitu 25 sampel. Jumlah tersebut diasumsikan tidak mampu mencakup keberadaan telur cacing. Tantri dkk (2013) menggunakan 80 sampel feses sapi untuk mengetahui Prevalensi dan Intensitas Telur Cacing Parasit pada Feses Sapi (Bos sp.) Rumah Potong Hewan (RPH) Kota Pontianak Kalimantan Barat, sedangkan Nezar (2014) menggunakan 64 sampel untuk mengetahui jenis cacing pada feses sapi di TPA Jatibarang dan KTT Sidomulyo Desa Nongkosawit Semarang.

Di samping itu, sapi yang diambil fesesnya sebagai sampel berumur sekitar 2 5 tahun. Menurut Villalba et al (2014), ternak ruminansia yang sudah dewasa atau pernah mengalami infeksi sebelumnya, maka rumennya akan kebal terhadap infeksi baru. Ruminansia tersebut belajar mengobati diri sendiri terhadap parasit gastrointestinal dengan meningkatkan konsumsi senyawa sekunder dari tanaman di sekitarnya. Hal ini terjadi pada sapi di TPAS Tamangapa yang memakan sampah organik (limbah sayur segar) sebagai salah satu asupannya.

Penelitian yang dilakukan pada musim kemarau juga berpengaruh. Musim kemarau berhubungan dengan tingkat kejadian cacing yang rendah disebabkan karena musim kemarau dapat mengganggu perjalanan siklus hidup cacing. Kondisi tanah yang kering dan atmosfer yang cukup panas menyebabkan feses cepat mengering mengakibatkan telur cacing menjadi rusak dan mati (Sayuti, 2007).

Berdasarkan perhitungan prevalensi, diketahui bahwa prevalensi infeksi cacing pada sapi di Tempat Pembuangan Akhir Sampah (TPAS) Tamangapa Makassar adalah sebesar $12 \%$. Prevalensi infeksi tidak terlalu tinggi, tapi cukup diwaspadai.

Prevalensi infeksi cacing pada sapi di setiap wilayah berbeda. Hal tersebut dapat disebabkan oleh perbedaan geografis yang mempengaruhi keberadaan siput sebagai hospes antara (Mage et al., 2002). Dapat pula dipengaruhi oleh beberapa faktor antara lain manajemen pemeliharaan ternak, umur ternak, penggunaan anthelmintik, kualitas kandang, sanitasi, pendidikan dan status ekonomi peternak (Raza et al., 2009). Sapi yang digembalakan di TPAS Tamangapa 
Makassar dipelihara secara semiintensif. Sapi digembalakan di TPAS pada pagi hingga sore hari kemudian dikandangkan pada malam harinya. Sistem pengawasan terhadap kesehatan ternak kurang efektif karena tidak kolektif di satu tempat, sehingga lebih rentan terinfeksi cacing parasit. Kondisi kandang yang basah dan lembab karena berada dalam lingkungan TPAS juga menjadi faktor pertumbuhan pesat cacing parasit.

\section{KESIMPULAN}

Adapun kesimpulan pada penelitian ini adalah sebagai berikut:

1. Jenis telur cacing parasit yang terdapat pada feses sapi yang digembalakan di sekitar tempat pembuangan akhir sampah (TPAS) Tamangapa Makassar adalah Oesophagostomum sp. dan Cooperia sp.

2. Prevalensi telur cacing yang terdapat di tempat pembuangan akhir sampah (TPAS) Tamangapa Makassar, teridentifikasi memiliki prevalensi yang rendah sebesar $12 \%$.

\section{DAFTAR PUSTAKA}

Grabda J. 1991. Marine Fish Parasitology. Polish Scientific Publishers, Warsawa.

Kabata, Z. 1985. Parasites and Diseases of Fish Cultured in the Tropics. Taylor and Francis, London and Philadelphia.

Kertawirawan, IPA., Yasa, IMRY., dan INA. Adijaya. 2012. Efektivitas Penggunaan Ivermectin Untuk Pengendalian Parasit Cacing pada Usaha Tani Penggemukan Sapi Bali. Prosiding Seminar Nasional Teknologi
Peternakan. Kementerian Ristek, Jakarta.

Levine, LD. 1990. Buku Pelajaran Parasitologi Veteriner. Terjemahan Gatut Ashadi. Gajah Mada University Press, Yogyakarta.

Mage, C., Henri, B. Marc, TJ., Daniel, R., and D. Gilles. 2002. Fasciola hepatica and Paramphistomum daubneyi: Changes in Prevalences of Natural Infections In Cattle and in Lymnaea truncatula from Central France Over The Past 12 Years. J Vet. Res. 33(5): 439-447.

Nezar, MR. 2014. Jenis Cacing Pada Feses Sapi di TPA Jatibarang dan KTT Sidomulyo Desa Nongkosawit Semarang. Skripsi: Matematika dan Ilmu Pengetahuan Alam, Universitas Negeri Semarang, Semarang.

Paly, B. 2013. Pertumbuhan Gross dan Net Populasi Ternak Sapi di Sulawesi Selatan. Biogenesis. 1(1): 33-40.

Pusarawati, S. 2013. Atlas Parasitologi Kedokteran. EGC, Jakarta.

Rahayu, S. 2015. Prevalensi Nematodiasis Saluran Pencernaan Pada Sapi Bali (Bos sondaicus) di Kecamatan Maiwa Kabupaten Enrekang. Skripsi: Fakultas Kedokteran Universitas Hasanuddin, Makassar.

Raza, MA., Murtaza, S., Bachaya, HA., and A, Hussain. 2009. Prevalence of Paramphistomum cervi in ruminants slaughtered in district Muzaffar Garh. Pakistan Vet J. 29(4): 214-215.

Sayuti, L. 2007. Kejadian Infeksi Cacing Hati (Fasciola spp) Pada Sapi Bali di Kabupaten Karangasem, Bali. Skripsi: Fakultas Kedoktaran Hewan Insitut Pertanian, Bogor.

Setiawan, D. 2014. Studi Kelayakan Usaha Peternakan Sapi Pedaging di Kalangan Petani di Dusun Getasan, Desa Getasan, Kecamatan Getasan, Kabupaten Semarang. Skripsi: 
Fakultas Keguruan dan Ilmu Pendidikan Unversitas Kristen Satya Wacana, Saligata.

Soulsby, EJL. 1982. Helminths, Arthropods and Protozoa of Domesticated Animals. $7^{\text {th }}$ Ed. Bailliere Tindall, London.

Tantri, N., Setyawati, TR., dan S. Khotimah. 2013. Prevalensi dan Intensitas Telur Cacing Parasit pada Feses Sapi (Bos sp.) Rumah Potong Hewan (RPH) Kota Pontianak Kalimantan Barat. Jurnal Protobiont. 2: 102-106.

Villalba, JJ., Miller, J., Uungar, ED., Landau, SY., and J. Glendinning. 2014. Ruminant self-medication against gastrointestinal nematodes: evidence, mechanism, and origins. Parasite. 21(31):

http://doi.org/10.1051/parasite/201 $\underline{4032}$

Vivi, A. 2015. Kejadian Nematodiasis Gastrointestinal pada Pedet Sapi Bali di Kec. Marioriwawo, Kab. Soppeng. Skripsi: Fakultas Kedokteran Universitas Hasanuddin, Makassar.

Widjaja, J., Leonardo, TL., Oktaviani., dan Puryadi. 2014. Prevalensi dan jenis telur cacing soil transmitted helmints (STH) pada sayuran kemangi pedagang ikan bakar di Kota Palu. Jurnal Epidemiologi dan Penyakit Bersumber Binatang. 5(2): 61-66

Yelifari, L., Bloch, P., Magnussen, P., Lieshout, L. van., Dery, G., Anemana, S., Agongo, E., and AM, Polderman. 2005. Distribution of human Oesophagostomum bifurcum, hookworm and Strongyloides stercoralis infections in northern Ghana. Transactions of The Royal Society of Tropical Medicine and Hygiene. $\quad$ 99(1): 32-38. https://doi.org/10.1016/j.trstmh.200 $\underline{4.02 .007}$
Zajac, AZ., and GA. Conboy. 2012. Veterinary Clinical Parasitology. 8 $^{\text {th }}$ Edition. p 811. 